się recenzji i polemik wśród polskich patrologów. Dodam jeszcze, że książka jest wzorowo zredagowana i jedyną rzeczą, która można jej wytknać to brak indeksu nazw geograficznych. Przy dużej ilości omawianych, bądź wspominanych synodów, przy znacznej ruchliwości głównych i pobocznych bohaterów książki, taki indeks z pewnością ułatwił by ,żeglowanie” po Imperium.

\title{
PS
}

I jeszcze jedna uwaga - w ostatnich słowach swej książki Autor pisze: ,jest [Nicea] jednym z mitów założycielskich Kościoła, podobnym do tych, które mają inne społeczności. Czcigodnym mitem, starszym niż król Artur czy bitwa pod Grunwaldem, ale podobnie opartym na historycznym wydarzeniu. Myślę, że nic Kościołowi nie zaszkodzi, jeżeli sobie to uświadomi, jak narodowi polskiemu nie zaszkodzi historyczna prawda o Krzyżakach" (s. 215). Kościołowi, mam nadzieję, nie zaszkodzi - choć może, ale co do tego Grunwaldu... Czcigodny Ojcze Profesorze, to jak to jest?, to i Długosz niewiarygodny?, to znaczy, że Krzyżacy nam wtedy „wsypali”?, że to my wyrżnęliśmy załogę Gdańska? Ojcze Profesorze - litości!

Wojciech Stawiszyński

\section{Steven RUNCIMAN, Zapomniana stolica Bizancjum. Historia Mistry i Pelo- ponezu, thum. Norbert Radomski, Poznań 2013, Dom Wydawniczy REBIS, sS. 203.}

Sir S. Runciman (7 VII 1903 - 1 XI 2000) był jednym z najbardziej uznanych i wpływowych brytyjskich historyków, zajmujących się epoką średniowiecza. W latach 1942-1945 wykładał historię i sztukę bizantyjską na Uniwersytecie Stambulskim. Owocem rozpoczętych tam badań było jego najsłynniejsze dzieło: A History of the Crusades, które zostało wydane w trzech tomach w latach 19511954 przez wydawnictwo Uniwersytetu w Cambridge (wszystkie trzy tomy ukazały się w polskim przekładzie J. Schwakopfa w 1987 r. za sprawą Państwowego Instytutu Wydawniczego pod tytułem Dzieje wypraw krzyżowych), będąc jedną z pierwszych anglojęzycznych syntez na temat wypraw krzyżowych. Jednak polskiemu Czytelnikowi Autor ten znany jest również z wielu innych uznanych prac w świecie naukowym, których polskie wydanie wielokrotnie wznawiano. Są to: Schizma wschodnia (tłum. J. Gawroński, Warszawa 1963, Pax); Upadek Konstantynopola (tłum. A. Dębnicki, Warszawa 1968, Państwowe Wydawnictwo Naukowe); Ostatni renesans bizantyński (tłum. J. Marzęcki, Warszawa 1973, Pax); Wielki Kościół w niewoli (tłum. J.S. Łoś, Warszawa 1973, Pax); Teokracja bizantyjska (tłum. M. Radożycka, Warszawa 1982, Pax); Manicheizm średniowieczny (tłum. J. Prokopiuk - B. Zborski, Gdańsk 1996, Wydawnictwo Marabut); Nieszpory Sycylijskie (tłum. Ł. Modelski - O. Tyciński, Katowice 1997, Książnica); dalsze informacje na temat Autora wraz z bibliografiąjego publikacji można znaleźć na stronie internetowej: http://en.wikipedia.org/wiki/Steven_Runciman [dostęp: 11 III 2014] 
(zob. też G. Constable, Sir Steven Runciman, 7 July 1903 - 1 November 2000, „Proceedings of the American Philosophical Society" 147 (2003) nr 1, 95-101).

S. Runciman wielokrotnie podróżował na Peloponez i był zauroczony historycznym miasteczkiem Mistra, leżącym w pobliżu ruin starożytnej Sparty na zboczach gór Tajget, które często odwiedzał, w efekcie czego powstała książka Zapomniana stolica Bizancjum. Historia Mistry i Peloponezu. Recenzowana praca ukazała się w roku 1980 (S. Runciman, Mistra. Byzantine Capital of the Peloponnese, London 1980, Thames and Hudson), natomiast jej reprint, uzupełniony o przedmowę Johna Freely, został wydany w 2009 r. pod zmienionym tytułem: The Lost Capital of Byzantium: The History of Mistra and the Peloponnese, London 2009, I.B. Tauris \& Co Ltd (kolejne wydania ukazały się w roku 2010 i 2013).

Zapomniana stolica Bizancjum obejmuje 203 strony i składa się z 12 rozdziałów, które zostały poprzedzone (poza Przedmowa, s. 9-13) odautorskim Wstęem (s. 15-16) i domknięte końcowym Epilogiem (s. 188-190). Statystyczna analiza „czystego” tekstu (bez załączonych map i ilustracji) tej krótkiej rozprawy (Wstęp, 12 rozdziałów, Epilog) wskazuje, że tekst obejmuje w sumie 173 strony (daje to średnio 12,357 stron na rozdział). Przy tym liczba stron poszczególnych części jest następująca: Wstęp (2), rozdz. I (9), rozdz. II (16), rozdz. III (11), rozdz. IV (15), rozdz. V (11), rozdz. VI (11), rozdz. VII (17), rozdz. VIII (17), rozdz. IX (13), rozdz. X (12), rozdz. XI (19), rozdz. XII (17), Epilog (3). Można zatem odnieść wrażenie, że dla Autora zgoła najważniejszą kwestią w całej pracy był rozdz. XI: Rzady niewiernych (s. 152-170) oraz rozdz. XII: Koniec dawnej Mistry (s. 171-187), ponieważ są one jej najdłuższymi rozdziałami. Są to, rzec by można, rozdziały pesymistyczne, które ukazująjak barbarzyńska bezmyślność może unicestwić w stosunkowo krótkim czasie ogromny wysiłek wcześniejszych pokoleń. Zapewne nie przypadkiem refleksja taka wychodzi spod pióra głębokiego znawcy Bizancjum, który pisząc ją dobiegał 80-tki. Ten kierunek rozważań zapowiada zresztą sam Autor we Wstęie, gdzie stwierdza, że napisana przez niego praca nie jest ani przewodnikiem, ani też panegirykiem na cześć Mistry. Autor chce „ukazać całe dzieje Mistry, wyjaśnić, jak doszło do jej powstania, omówić rolę, jaką odegrała w ostatnich dwóch stuleciach średniowiecza, i prześledzić smutną historię jej długiego upadku" (s. 15).

W ten sposób cztery pierwsze rozdziały rozprawy (I. Nizina Lakońska, s. 1725; II. Przybycie Franków, s. 26-43; III. Założenie Mistry, s. 44-54; IV. Powrót Greków, s. 55-69) dotyczą historycznego opisu, wyjaśniającego okoliczności założenia Mistry przez frankońskich władców z dynastii Villehardouin oraz ich dalszych losów na obszarze Księstwa Achai. Rozdz. V. Despota Manuel (s. 70-80) otwiera cztery kolejne rozdziały książki (VI. Despota Teodor I Paleolog, s. 81-91; VII. Despota Teodor II Paleolog, s. 92-108; VIII. Ostatni despoci, s. 109-126), w których S. Runciman przygląda się bliżej sylwetkom bizantyjskich władców prowincji Peloponezu, która stała się od 1349 r. niezależnym apanażem despotów, zwanym odtąd jako Despotatem Morei (s. 74). Natomiast ostatnie cztery rozdziały (IX. Budowle Mistry, s. 127-139; X. Filozofowie z Mistry, s. 140-151; XI. Rzady 
niewiernych; XII. Koniec dawnej Mistry) zostały poświęcone m.in.: architekturze monumentalnej Mistry; znanemu filozofowi bizantyjskiemu, Pletonowi (ok. 1355 - 26 VI 1452), który przybył do Mistry z Konstantynopola ok. roku 1407 (s. 142); epizodowi przejęcia władzy nad całym Peloponezem przez Wenecjan w latach 1690-1718 (s. 159-166) oraz greckiemu powstaniu i zburzeniu Mistry przez Ibrahima Paszę (ok. 1789 - 10 XI 1848, władca Egiptu od 2 III 1848) (s. 181-187).

Poza tekstem głównym praca została uzupełniona również o Spis map, który składa się z czarno-białych odwzorowań Peloponezu (s. 38-39) i samej Mistry (s. 126) oraz ryciny drzewa genealogicznego Paleologów i Kantakuzenów (s. 196-197). Jeszcze innym ważnym dodatkiem są kolorowe fotografie w liczbie 31, zamieszczone między stronami 64-65 oraz 128-129, które w większości przedstawiają współcześnie zachowane zabytki Mistry, jak również znajdujące się wewnątrz świątyń freski. Szkoda tylko, że załączone zdjęcia nie zostały ponumerowane i wprowadzone, na przykład, do osobno sporządzonego na końcu książki „Spisu ilustracji”. W ten sposób polski wydawca pomógłby Czytelnikowi w efektywniejszym poruszaniu się po książce. Jednak generalnie należy podkreślić, że wszystkie te „dopełnienia” znacząco wzbogacają recenzowaną publikację i dają Czytelnikowi możliwość swoistego wczucia się w niezwykłą atmosferę „zapomnianej stolicy” imperium bizantyjskiego.

Na końcu książki, oprócz standardowo sporządzonego Indeksu (s. 199-203), znajduje się także Nota bibliograficzna (s. 191-195), która może okazać się szczególnie przydatna dla tych Czytelników, którzy chcą poszerzyć swoją wiedzę na temat Mistry oraz sięgnać po źródła i opracowania, z jakich korzystał sam Autor. Załączona bibliografia nie została jednak przedstawiona w formie wykazu bibliograficznego, lecz w formie historiograficznego komentarza, który niejako wzbogaca wiedzę Czytelnika. Autor uprzedza zresztą o tym rozwiązaniu już we Wstępie. Ponadto wyjaśnia, że „w książce takiej jak ta pełne noty bibliograficzne byłyby nie na miejscu" (s. 16). W konsekwencji praca nie zawiera żadnych przypisów.

Jednak wydawnictwo Rebis lub sam polski thumacz pracy S. Runcimana mogli zadbać o identyfikację cytatów, zamieszczając stosowne przypisy podtekstowe. I tak na s. 145 (lin. 13 od dołu) znajduje się niezidentyfikowany cytat z Pletona: „warunkiem ozdrowienia politycznego jest reforma ustroju”. Tymczasem cytat ten pochodzi z: G. Plethonis, De Rebus Peloponnesiacis. Oratio II, PG 160, 844A. Podobnie jest na s. 148-149 (lin. 1 od dołu i lin. 1 od góry), gdzie zostały zacytowane słowa Pierre'a de Ronsarda (11 IX 1524 - 27 XII 1585), będące tytułem jednego z napisanych przez niego wierszy, które poświęcił Michałowi Marullusowi Tarchaniocie (ok. 1458 - 10 IV 1500): „,najznakomitszym greckim wodzem i poetą". Zamieszczony tam cytat pochodzi z: P. Ronsard, Epitaphe de Marulle, w: Oeuvres complètes, t. 7, Librairie A. Franck, Paris 1866, 238-239. Kolejny niezidentyfikowany cytat, tym razem z dzieła Bernarda Randolpha (ok. 1643-1689), znajduje się na s. 156 (lin. 3-1 od dołu): „Miasto jest oddalone od morza i wolne od niebezpieczeństw z tamtej strony, jednak chętnie żeruje na nim lud Maniotów". Cytat ten pochodzi z: B. Randolph, The present state of the Morea, called 
anciently Peloponnesus, London $1689^{2}, 8$. W dalszej kolejności, na s. 164 (lin. 14-13 od dołu) zostały zacytowane słowa Vincenzo Coronellego (16 VIII 1650 - 9 XII 1718): „najpierw zwano Sparta, potem Lacedemonem, a teraz Misitrą”. Te zacytowane słowa pochodzą z: G.B. Moro - V. Coronelli, Morea, Negroponte \& Adiacenze, Venezia 1686, 32. Następny niezidentyfikowany cytat, z jednego z listów napisanych przez carycę Katarzynę II (2 V 1729 - 17 XI 1796, caryca Rosji od 9 VII 1762), znajduje się na s. 171 (lin. 5-3 od dołu): „Grecy, Spartiaci, zdegenerowali się, wolą grabież od wolności”. Jest to cytat pochodzący z: Documents of Catherine the Great. The Correspondence with Voltaire and the Instruction of 1767 in the English Text of 1768, ed. W.F. Reddaway, Cambridge 2012, 78. W końcu na s. 178 (lin. 14-12 od dołu) zostały przytoczone niezidentyfikowane bibliograficznie słowa Chateaubrianda (4 IX 1768 - 4 VII 1848), które pochodzą z: F.-R. de Chateaubriand, Travels in Greece, Palestine, Egypt, and Barbary, during the years 1806 and 1807, thum. F. Shoberl, t. 1, London 1812, 147 (wszystkie teksty są łatwo dostępne w zdigitalizowanej formie w internecie).

Nie udało się też niestety uniknąć polskiemu wydawcy książki S. Runcimana drobnych pomyłek edytorskich. Na zamieszczonych ilustracjach między s. 64-65 znajduje się błąd w komentarzu do jednego ze zdjęć (4 zdjęcie od końca), jest: „Afetndiko”, powinno być: „Aftendiko”. Na s. 164 (lin. 13 od dołu), jest: „Misitrą", powinno być: „Mistrą”.

Ponadto, Autor informuje Czytelnika w rozdz. VIII (Ostatni despoci, s. 114), iż nie można stwierdzić kategorycznie, w której świątyni w Mistrze 6 I 1449 r. został koronowany na cesarza Konstantyn XI Paleolog (8 II 1404 - 29 V 1453). Według S. Runcimana mogła być to katedra św. Dymitra lub kościół pałacowy św. Zofii. Jednak wydaje się, że znajdujący się w katedrze św. Dymitra marmurowy relief, przedstawiający dwugłowego orła, herb imperium bizantyjskiego, jest raczej dobitnym świadectwem, mówiącym nam o miejscu koronacji cesarza (zob. D.M. Nicol, Byzantium and Venice. A study in diplomatic and cultural relation, Cambridge 1992, 390).

Mimo tych niedociaggnięć, książka badacza tej miary co S. Runciman znajdzie sporą rzeszę Czytelników i jest warta polecenia. Zapomniana stolica Bizancjum to tytuł wręcz obowiązkowy dla każdego mediewisty, entuzjasty historii średniowiecza, czy zapalonego miłośnika Półwyspu Peloponeskiego. Dzięki barwnej opowieści Autora, Mistra, ostatni bastion bizantyjski, wręcz ponownie ożywa, odsłaniając niejako przed nami swoje barwne dzieje, które są warte poznania. Trudno zatem się nie zgodzić z J. Freely, który stwierdza w Przedmowie, że praca S. Runcimana ,jest [...] skarbnicą wiadomości na temat tego miejsca oraz jego dziejów, wskrzeszając jego przeszłość i przywracając je do życia w sposób nieosiaggalny dla dzieł historycznych lub przewodników dla turystów" (s. 9). 